\title{
Do Islamic versus conventional banks progress or regress in productivity level?
}

\author{
Ribed Vianneca W. Jubilee ${ }^{1,2}$, Fakarudin Kamarudin ${ }^{3 *} \mathbb{0}$, Ahmed Razman Abdul Latiff ${ }^{1}$, \\ Hafezali lqbal Hussain ${ }^{4,5}$ and Khar Mang Tan ${ }^{6}$
}

\begin{abstract}
This study assesses the differences between Islamic and conventional bank's productivity. Earlier studies on bank productivity focused on conventional banks, but few have been done on Islamic banks. Therefore, the present study attempts to close the gap in the literature by investigating the productivity of Islamic and conventional banks in the context of the Middle East, Southeast Asia and South Asia regions. The sample is comprised of 385 banks (66 Islamic banks and 319 conventional banks) from 18 countries with data observations from 2008 to 2017. Panel data techniques with DEA-based MPI will be employed to investigate the impact of selected important factor and bank productivity as indicated by total factor productivity changes (TFPCH). Based on the results, Islamic banks are more productive than conventional banks and the results from $t$ test are further confirmed by the results from nonparametric tests. These results are attributed to the progress in EFFCH. However, the mean difference between Islamic and conventional banks TFPCH is not statistically significant in all regions. The main benefit is that this work will hopefully provide additional insight and complement the existing studies on bank productivity of Islamic and conventional banks that are important to the banks, regulations, investors and researchers.
\end{abstract}

Keywords: Total factor productivity change, Malmquist productivity index, Islamic bank, Conventional banks, Middle East, Southeast Asia, South Asia

JEL Classifications: G21, G28

\section{Introduction}

Nowadays, the banking industry continues to grow, at least, until another form of banking becomes available, and Islamic banking begins to gain further attention from Islamic and contemporary economists. Islamic finance is important for Muslims who require financial instruments that follow the Islamic legal code called Shariah [50]. Moreover, Islamic banks also have the potential to reduce risks endemic to financial transaction which have implication for economic growth [28].

The inception of Islamic banking began more than 30 years ago, and since this time, the aggregate of banks

\footnotetext{
*Correspondence: fakarudin@upm.edu.my; fakarudinkamarudin@gmail.com

${ }^{3}$ School of Business and Economics, Universiti Putra Malaysia,

43400 Serdang, Selangor, Malaysia

Full list of author information is available at the end of the article
}

offering financial services has significantly grown to over 300 banks nowadays in over 75 countries from only one bank in 1975 [24]. Islamic finance is important for Muslims who require financial instruments that follow the Islamic legal code called Shariah [50]. Also, as the need for Shariah-compliant financial products and services increases, this sector will continue to rapidly grow in Muslim and non-Muslim market segments [13]. Referencing Table 1, it can be seen that within 9 years between 2009 and 2018, the total Shariah compliance assets significantly increased. Iran, Saudi Arabia, Malaysia, the United Arab Emirates and Kuwait remain the primary markets for Islamic financial banking based on total Shariah compliance assets. Notably, South Asia and Southeast Asia countries, including the Middle East, dominate Islamic financing from a global perspective [4]. Therefore, taking these findings into 
Table 1 Ten leading countries for Shariah-compliant assets. Source: The Asian Banker [59] and IFDI (2019)

\begin{tabular}{|c|c|c|c|c|c|}
\hline \multirow{2}{*}{$\begin{array}{l}\text { Year } \\
\text { Rank }\end{array}$} & \multicolumn{2}{|l|}{2009} & \multicolumn{3}{|l|}{2018} \\
\hline & Country & $\begin{array}{l}\text { Shariah-Compliant Assets } \\
\text { (\$ billion) }\end{array}$ & Rank & Country & $\begin{array}{l}\text { Shariah- } \\
\text { Compliant Assets } \\
\text { (\$ billion) }\end{array}$ \\
\hline 1 & Iran & 236.43 & 1 & Iran & 488 \\
\hline 2 & United Arab Emirates & 67.31 & 2 & Saudi Arabia & 390 \\
\hline 3 & Malaysia & 56.22 & 3 & Malaysia & 214 \\
\hline 4 & Saudi Arabia & 55.01 & 4 & United Arab Emirates & 194 \\
\hline 5 & Kuwait & 55.01 & 5 & Kuwait & 100 \\
\hline 6 & Bahrain & 38.58 & 6 & Qatar & 97 \\
\hline 7 & Qatar & 19.01 & 7 & Turkey & 39 \\
\hline 8 & Turkey & 13.76 & 8 & Bahrain & 35 \\
\hline 9 & Sudan & 6.12 & 9 & Bangladesh & 36 \\
\hline 10 & Bangladesh & 7.5 & 10 & Indonesia & 28 \\
\hline
\end{tabular}

account, it is important to comprehend the productivity and nature of both conventional and Islamic banking in these countries.

In principle, Islamic financial system abolishes interest, gambling, speculation, excessive uncertainty (gharar) and illegitimate transactions that are related to alcohol, tobacco, pornography and other activities which considered to be detrimental to the society [27]. Theoretically, Islamic banks which offer Shariah-compliant products can be separable from conventional bank associated with the difference in complexity, agency cost, level of maturity and development [11]. Further differences are evident concerning risk-taking, the price of money, income, the size of banks and so forth [26].

As Islamic banking is viewed as one of the rapidly rising markets, the industry is exposed to credit risk by lengthening borrowing via Murabaha and Ijarah in generating greater profitability. Furthermore, with non-standard financial agreements and varied methods of funding and intricacies related to managing risk brought about via the introduction of Shariah present further issues regarding Islamic banking to remain stabilised [36]. Islamic banking has the opportunity to utilise profit and loss sharing with respect to liabilities which intensifies credit risk [44]. Moreover, on the balance sheet's liability side, Islamic banks receive deposits founded on profit and loss sharing where they need to pay a profit while investing funds identified on the asset side. Given insufficient investment opportunities, Islamic banks typically have excessive liquidity assets, so liquidity risk is minimal [29]. While Islamic and conventional banks can be distinguished from each other, both banks have a same objective that prioritise the profitability. Simply put, productivity in generating profitability is an important area for both Islamic and conventional banks.
In light of the importance of profitability to Islamic and conventional banks, several studies have focused on analysing the efficiency of Islamic finance as a means of measuring the performance of banks [39, 50, 51, 57, $58,62]$, whereas scant research has been undertaken to examine the productivity levels of the Islamic and conventional banking sector as intermediaries [39]. Therefore, this paper will provide a better understanding and contribute to the literature relevant to productivity in banking sector.

Siddiqi [53] mentions that Islamic economic and finance theories are still underdeveloped. Therefore, this study proposes using real-life data to validate the foundational theories in terms of productivity perspective. Productivity is one of the crucial dimensions to measure the firm's performance [15]. The financial performance is a broad concept that takes into consideration of the productivity, profitability and growth. Profitability is the overall efficiency of the company that shows the ability of the firm to earn a profit. One of the primary goals of banks is to look after the interests of shareholders by maximising their return on investment and optimising profits. In order for the bank to get high profit, they need to be productive. However, some of study found that the lower level of productivity can lead to lower profitability of the banks [15]. So, this becomes the main issue. The productivity becomes the main issue because productivity can lead to the lower and higher profitability. So, banks cannot ignore the productivity if they want to increase their profit.

In the context of Islamic banks, similar goals are afforded as to those of conventional banks in maximising profits, although as mentioned previously, both differ as intermediaries. Conventional banks operate on an interest-based principle, whereas Islamic banks adhere to the 
interest-free principle by replacing it with profit and loss sharing in performing day-to-day operations founded on Shariah rules and principles [7], although to maximise profits, banks need to be productive, which is directly linked to their efficiency by converting inputs such as capital, raw materials and labour into outputs. Accordingly, as the throughput of outputs increases more rapidly compared to inputs, the efficiency and productivity of banks will also increase. In this situation, productivity determines the level of efficiency in utilising resources (input) to produce outputs.

Globally, the market share of Islamic banking in the financial industry remains low, but in many regions is quickly growing, mainly in the Asian and Middle East regions [33]. According to Houben [31], Southeast Asia, with its ever-increasing Muslim population, receives minimal attention globally. This fact is also supported by Kamarudin et al. [39]. As Islamic finance is increasingly becoming an institutionalised part of the global capital market, it has the distinct potential to rapidly expand and contribute to economic growth [32]. In this context, it is therefore important for Islamic banks to remain productive, in order to remain competitive and contribute towards economic growth. Therefore, instead of just focusing on conventional banks, it is more justifiable if not beneficial, to compare the productivity of Islamic banks.

The lack of comprehensive study on productivity of Islamic and conventional banks inspires this study to investigate the level of productivity amid Islamic and conventional banking sector in the three regions, consisting of South Asia (SA), Southeast Asia (SEA) and Middle East (ME) regions. This study also serves as a continuation to the ongoing debate on whether Islamic banks are more productive relative to conventional banks and vice versa. Hence, this paper focuses on the question whether the productivity of Islamic bank differs from the productivity of conventional bank?

This paper begins with a brief review of related studies and followed by data and methodology, empirical results and conclusion.

\section{Literature review}

The role of banking sector as a form of financial intermediation which is part of the financial institution cannot be readily ignored, given it leads to stable economic growth and development. Endogenous growth theory argues that economic growth is primarily result of internal forces rather than external ones through the channel of productivity can be tied directly to faster innovation and more investments in human capital [61]. Business companies wish to be in a position to regulate their spending and overheads, in order to generate greater profits for stakeholders, similarly, conventional and Islamic banks also seek to improve their productivity given the contribution they make towards economic growth and sustainability. The Islamic banking system plays a similar role but differs slightly compared to the conventional banking system. Islamic banks are considered as a replacement or an alternate option in the provision of banking product and services in accordance with Islamic (Shariah) principles.

Nevertheless, the theory in this area fails to make any obvious prediction as to whether Islamic banks should be more efficient or productive compared to conventional banks [11]. Although productivity is extremely important in Islamic banking in order to gain high profitability, given financing decisions are based on the productivity of the investment in the selected project. Moreover, the Shariah Advisory Committee plays a key part in this respect Islamic banks, in affirming the behaviour stakeholders' in following the principles that govern Islamic law. Moreover, the Shariah Advisory Committee is ultimately responsible for minimising information asymmetries and agency costs within an Islamic bank. According to Jensen and Meckling [34], the existence of conflicts of interest between the principal and agent can influence the performance of organisations.

In this regard, information asymmetry and agency conflicts should be less in Islamic banks compared to their conventional counterparts $[48,60]$. Therefore, with the intervention of the Shariah Advisory Committee in monitoring the operations of Islamic banks, conflicts between the principal and agent(s) can be prevented and reduce the agency costs. Ang et al. [6] found that external monitoring produces lower agency costs and thereby increasing the efficiency of banks, leading to high productivity. On the other hand, the opposite may occur given the effect of various productivity determinants are distinctly different in Islamic banks compared to conventional banks such the complexity, level of maturity and development.

Kopleman [43] defines productivity as the relationship between the amount of one or more physical output/s to the associated physical inputs used in production. In other words, they asserted that total production (output) is influenced by the amount of capital invested and the amount of involved labour. Productivity can also be broken down into smaller segments according to Fare et al. [23], based on changes in efficiency or fluctuations in order to compensate for lost ground and also through innovative technological changes, assuming that the outputs are equal equivalent to outputs, and the growth index total factor productivity captures the advancements or changes in technology. Therefore, total factor productivity can be considered equivalent to changes in 
technology (from a technical perspective) which can be gauged as a shift in performance, which can accordingly be adjusted by altering the chosen input. Fundamentally, higher productivity will lead to higher bank profitability $[39,54,56]$.

In other words, in the context of the banking industry, when the productivity level is increased, the additional output can be therefore be produced from the given amount of input. Accordingly, Cobb-Douglas Production Functions theory will be employed in this study to examine the productivity level between the Islamic and conventional banking sector in the ME, SEA and SA regions. A few studies have found that Islamic banks are significantly more productive compared to conventional banks, other studies have revealed contrary findings and a few studies have revealed that they are similar (no variation) regarding productivity.

More recently, Saleh et al. [52] reveal that the Gulf Cooperation Council (GCC) banks encountered a decline in productivity after the global financial crisis of 20082009. They also indicate that the disparity in inefficiency between Islamic and conventional banks has narrowed substantially and that Islamic banks have been able to cross and reduce the gap with conventional banks over the study period from 2005 to 2014 . This finding is also supported by Alsharif et al. [5] in which six GCC countries were studied between 2005 and 2015. The findings suggest that Islamic banks are less productive than conventional banks. Moreover, the findings suggest that the Basel III agreement hampered the productivity of the GCC banks, and this detrimental impact is greater for Islamic banks.

Another study by Alexakis et al. [3] reported that in 2008/09, both Islamic and conventional banks experienced a decline in productivity with conventional banks more negatively impacted. The global financial crisis can possibly be connected with this decline in the Gulf Cooperation Council (GCC) banking sector, which was supported by Maredza and Ikhide [45]. The results of this study indicated that there were differences in technological and technical efficiency in Islamic banks, which may be historically related to these banks in the GCC. While this sector is still developing, there are a number of mature Islamic banks in the GCC, although this mix is possibly varied given the assortment of financial products, bank status, clients and innovation.

On the other hand, Rodoni et al. [49] undertook a comparison of the productivity and efficiency of the Islamic banking sector between 2009 and 2013 in Pakistan, Indonesia and Malaysia; the data included 31 banks across these three countries. Using the Malmquist productivity index (MPI) to gauge productivity and Data Envelopment Analysis (DEA) in gauging efficiency the findings from the study found that the efficiency of the sector in Malaysia was far better compared to Indonesia while in Pakistan, the rate of efficiency was near to $100 \%$ during this period.

Kamarudin et al. [39] compared the productivity of 29 Islamic banks in SEA (Malaysia, Indonesia and Brunei) between 2006 and 2014. Using nonparametric DEAbased MPI methods, the researchers approximated the total factor productivity of the banks found that statistically, there was nil variance between the productivity and efficiency and productivity of local and international managed banks given the similar technologies and population.

In another study by Doumpos et al. [21], they investigated the financial robustness of 52 Islamic windows, 347 conventional banks and 101 Islamic banks between 2000 and 2011 by considering 57 member countries of the Organisation of Islamic Cooperation (OIC). The findings from the study indicated that each bank varied concerning the employment of financial ratios, although no difference was evident from a statistical viewpoint for overarching financial robustness between the banks.

Nevertheless, Mobarek and Kalanov [46] examined performance comparatively between Islamic and conventional banks 18 Organisation of Islamic Conference (OIC) countries regarding the pre-global financial crisis period and the actual global financial crisis period between 2004 and 2006 and between 2007 and 2009, respectively. The research was founded on the crosssectional data of 307 conventional banks and 101 Islamic banks employing DEA and stochastic frontier analysis (SFA) methods in measuring efficiency. The study indicated that the efficiency of conventional banks was higher compared to Islamic banks between 2006 and 2009 , which may be due to the mean value of the efficiency score being larger in conventional banks making such a comparison non-equivalent.

Kamarudin et al. [38] investigated the profit, revenue and costs efficiency of 74 banking institutions (47 conventional banks and 27 Islamic banks) in the GCC region between 2007 and 2011. Here, the efficiency level was gauged using the DEA technique by employing the intermediation method. The researchers found that conventional banks displayed higher levels of efficiency based on three determinants: revenue, profit and cost. Moreover, they suggest that the primary determinant with respect to the profit efficiency level was the efficiency level associated with revenue.

Therefore, in summary, most studies documented varied and mixed findings on the level of efficiency level amid Islamic banks and conventional banks globally, whereas on the other hand, little has been undertaken, if anything, to explore Islamic and conventional banks 
productivity levels. Also, there is less evidence to suggest the productivity level of both types of banks has been conducted in the Asian region, given the strong presence of Islamic banks [39]. Hence based on this deficiency, this research aims to offer evidence empirically mainly on the level of productivity in the Islamic and conventional banks sector.

\section{Methods}

\section{Sources of data}

The dataset used in this study consisted of Islamic banks and conventional banks from Middle East (ME), Southeast Asia (SEA) and South Asia (SA) countries between the period 2008 and 2017 given these three regions are representative of Islamic banking and finance globally [42]. The global financial crisis that occurred between 2008 and 2009 is also taken into consideration in this study, which applies a 'dummy' variable to represent this period to avoid any possible biasedness. The sample size of the study consisted of Islamic and conventional banks from 18 countries, (11 from the ME, 4 from SEA and 3 from SA).

The data source employed in this study comprised of information relating to Islamic and conventional banks collected from within the ME, SEA and SA regions between 2008 and 2017. All data were obtained from the Fitch Connect database produced by Fitch Solutions.
Fitch connect is an online repository of data that comprises financial reports, accounting ratios and credit ratings of more 30,000 banks globally including the Islamic and conventional banking sectors. To compare the chosen banking institutions across the three regions (ME, SEA and SA), the currency will be depicted in US dollars.

In total, 385 banks (66 Islamic banks and 319 conventional banks) from 18 countries with dual-banking system are selected in this study as represented in Table 2 . Also, to maintain homogeneity, all investment banks, insurance companies and finance companies were excluded in this study. The data of Islamic banks are obtained on the basis of an Islamic subsidiary. The country income level is taken from World Bank Database.

\section{DEA-based Malmquist Productivity Index (MPI)}

The data envelopment analysis (DEA) technique was developed by Charnes et al. [18] in which they proposed that the greater the output generated from inputs, the greater the efficiency level associated with the production process. Emrouznejad and Yang [22] affirmed that there had been exponential growth in DEA-related studies, especially given the work of Charnes et al. [18]. Therefore, this confirms that DEA has been acknowledged as a contemporary tool in measuring performance in the diversified fields of management science.

Table 2 Sample data. Source: Fitch Connect database

\begin{tabular}{|c|c|c|c|c|c|}
\hline No. & Country & Income group & Region & No. of Islamic bank & $\begin{array}{l}\text { No. of } \\
\text { conventional } \\
\text { bank }\end{array}$ \\
\hline 1 & Bahrain & High & Middle East & 8 & 12 \\
\hline 2 & Egypt & Lower Middle & Middle East & 1 & 23 \\
\hline 3 & Iran & Upper Middle & Middle East & 1 & 8 \\
\hline 4 & Iraq & Upper Middle & Middle East & 1 & 3 \\
\hline 5 & Jordan & Upper Middle & Middle East & 2 & 11 \\
\hline 6 & Kuwait & High & Middle East & 1 & 4 \\
\hline 7 & Lebanon & Upper Middle & Middle East & 2 & 31 \\
\hline 8 & Oman & High & Middle East & 2 & 7 \\
\hline 9 & Qatar & High & Middle East & 3 & 5 \\
\hline 10 & Saudi Arabia & High & Middle East & 3 & 8 \\
\hline 11 & UAE & High & Middle East & 7 & 14 \\
\hline 12 & Brunei & High & South East Asia & 1 & 1 \\
\hline 13 & Indonesia & Lower Middle & South East Asia & 8 & 92 \\
\hline 14 & Malaysia & Upper Middle & South East Asia & 13 & 31 \\
\hline 15 & Singapore & High & South East Asia & 1 & 8 \\
\hline 16 & Bangladesh & Lower Middle & South Asia & 4 & 37 \\
\hline 17 & Pakistan & Lower Middle & South Asia & 7 & 23 \\
\hline \multirow[t]{2}{*}{18} & Maldives & Upper Middle & South Asia & 1 & 1 \\
\hline & Total & & & 66 & 319 \\
\hline
\end{tabular}


In the context of this study, efficiency and productivity in an organisation are interrelated, although efficiency is static given it fails to consider the time taken for production, which is important. Accordingly, this shows that when productivity measures alter or change, the level of efficiency also changes. Therefore, it is vital to measure productivity. Fundamentally, the ratio between inputs and outputs can be used to determine productivity.

MPI is occasionally referred to as Total Factor Productivity (TFP), which can assess any change of efficiency and frontier technology in terms of progress or regress over time. Moreover, MPI has been used in many studies for DEA analysis of efficiency changes in diversified fields of management science across various industries and countries.

Output-based MPI was used to understand and gauge the change in the productivity of banks and also to determine the change in TFP Change (TFPCH) to Technical Change (TECHCH) and Efficiency Change (EFFCH). According to Fare et al. [23], the changes in Scale Efficiency Change (SECH) and Pure Technical Change $(\mathrm{PTECH})$ resulted from changes in EFFCH. Figure 1 illustrates the interactive relationship among the efficiency indices

Here, MPI measures the productivity change from period $t$ to $t+1$, which reflects to a reference period technology. Thus, the MPI in relation to technology in period $t$ is:

$$
M_{0}^{t}=\frac{D_{0}^{t}\left(x^{t+1}, y^{t+1}\right)}{D_{0}^{t}\left(x^{t}, y^{t}\right)} .
$$

Corresponding output based MPI concerning technology in period $t+1$ is:

$$
M_{0}^{t+1}=\frac{D_{0}^{t+1}\left(x^{t+1}, y^{t+1}\right)}{D_{0}^{t+1}\left(x^{t}, y^{t}\right)} .
$$

Given it is complicated in choosing among period $t$ and $t+1$ as a benchmark period, an output-based MPI is defined as the geometric mean of Eqs. (1) and (2), [23]:

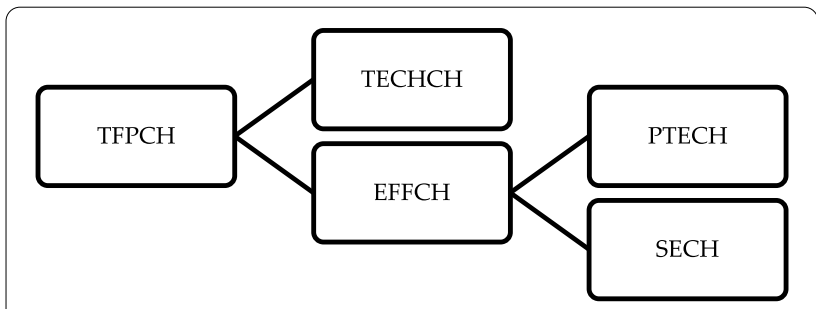

Fig. 1 Interactive relationship among the MPI efficiency indices

$$
\begin{aligned}
& M_{0}^{t, t+1}\left(x^{t+1}, y^{t+1}, x^{t}, y^{t}\right) \\
& \quad=\left[\left(\frac{D_{0}^{t}\left(x^{t+1}, y^{t+1}\right)}{D_{0}^{t}\left(x^{t}, y^{t}\right)}\right) \times\left(\frac{D_{0}^{t+1}\left(x^{t+1}, y^{t+1}\right)}{D_{0}^{t+1}\left(x^{t}, y^{t}\right)}\right)\right]^{1 / 2} .
\end{aligned}
$$

Accordingly, this can be broken down into efficiency change $\left(\mathrm{EFFCH}^{t, t+1}\right)$ as well as technological change $\left(\mathrm{TECHCH} \mathrm{H}^{t, t+1}\right)$. As proposed by Fare et al. [23], an equivalent way of writing the MPI index is given below:

$$
\begin{aligned}
& M_{0}^{t, t+1}\left(x^{t+1}, y^{t+1}, x^{t}, y^{t}\right) \\
&= \underbrace{\frac{D_{0}^{t+1}\left(x^{t+1}, y^{t+1}\right)}{D_{0}^{t}\left(x^{t}, y^{t}\right)}}_{\mathrm{EFFCH}^{t, t+1}} \\
& \times \underbrace{\left[\left(\frac{D_{0}^{t}\left(x^{t+1}, y^{t+1}\right)}{D_{0}^{t+1}\left(x^{t+1}, y^{t+1}\right)}\right) \times\left(\frac{D_{0}^{t}\left(x^{t}, y^{t}\right)}{D_{0}^{t+1}\left(x^{t}, y^{t}\right)}\right)\right]^{1 / 2}}_{\text {TECHCH }}
\end{aligned}
$$

where $M$ represents the level of productivity change as measured by a shift in frontier measured at years' $t$ and $t+1$ in which most of the recent production point $\left(x^{t+1}, y^{t+1}\right)$ correspond to the previous production point $\left(x^{t}, y^{t}\right)$. However, when $M>1$ it says that period $(t+1)$ productivity is higher compared to period $t$ productivity. Although when $M<1$, it says $(t+1)$ productivity is less compared to period $t$ productivity which says that productivity regress and $M=1.000$ correspond to inaction (no TFP change). Lastly, output distance functions are represented by $D$ 's. The interrelation among the MPI and its two sub-indices can be shown as:

$$
M_{0}^{t, t+1}=\text { Efficiency Change } \times \text { Technical Change }
$$

where

$$
\text { Efficiency Change }=\frac{D_{0}^{t+1}\left(x^{t+1}, y^{t+1}\right)}{D_{0}^{t}\left(x^{t}, y^{t}\right)}
$$

Technical Change

$$
=\left[\left(\frac{D_{0}^{t}\left(x^{t+1}, y^{t+1}\right)}{D_{0}^{t+1}\left(x^{t+1}, y^{t+1}\right)}\right) \times\left(\frac{D_{0}^{t}\left(x^{t}, y^{t}\right)}{D_{0}^{t+1}\left(x^{t}, y^{t}\right)}\right)\right]^{1 / 2} .
$$

Fare et al. [23] proposed that the index for efficiency change can additionally be broken down into its agreed detailed parts of PTECH ( $\triangle$ PureEff $\left.{ }^{t, t+1}\right)$ measured in relation to the VRS technology and part of SECH $\left(\Delta \mathrm{Scale}^{t, t+1}\right)$, which captured the change in the variation among the constant returns to scale (CRS) variable and returns to scale (VRS) technologies which can be described as given below: 
Efficiency Change $=\Delta$ PureEff ${ }^{t, t+1} \times \Delta$ Scale $^{t, t+1}$

where

$$
\begin{aligned}
& \Delta \text { PureEff }^{t, t+1}=\frac{D_{\mathrm{VRS}}^{t+1}\left(x_{j}^{t+1}, y_{j}^{t+1}\right)}{D_{\mathrm{VRS}}^{t}\left(x_{j}^{t}, y_{j}^{t}\right)} \\
& \Delta \mathrm{Scale}^{t, t+1}=\frac{D_{\mathrm{CRS}}^{t+1}\left(x_{j}^{t+1}, y_{j}^{t+1}\right) / D_{\mathrm{VRS}}^{t+1}\left(x_{j}^{t+1}, y_{j}^{t+1}\right)}{D_{\mathrm{CRS}}^{t}\left(x_{j}^{t}, y_{j}^{t}\right) / D_{\mathrm{VRS}}^{t}\left(x_{j}^{t}, y_{j}^{t}\right)} .
\end{aligned}
$$

The analysis can also be used to examine the losses or gains relating to the productivity sources to compare the values of both TECHCH and EFFCH. When $\mathrm{EFFCH}>\mathrm{TECHCH}$, it then means that the gains in productivity are primarily from the improvement in efficiency. While when $\mathrm{EFFCH}<\mathrm{TECHCH}$, the gains in productivity are mainly resulting from technological progression.

Therefore, to summarise the analysis of the first stage the TFPCH of banks were determined by employing output-based MPI. Next, VRS technology was used to measure TFPCH $\left(M_{0}^{t, t+1}\right)$ relative to efficiency change $(\mathrm{EFFCH})$ and technical change (TECHCH) as given in Eq. (5). Moreover, as proposed by Fare et al. [23], efficiency change $(\mathrm{EFFCH})$ was then broken down further into the element of pure technical change (PTECH) which was determined based on the VRS technology. Accordingly, this was part of the scale efficiency change $(\mathrm{SECH})$ employed to capture the variance among the constant returns to scale (CRS) and variable returns to scale (VRS) technologies as shown in Eq. (8).

The scores representing efficiency were constrained in order to remain amid zero and one and the year 2007 was used as the reference year. The MPI and its constituent parts started with a value of 1.000 . Therefore, an efficiency value less (higher) than one for a bank in the following years meant that it was performing below (above) the frontier. Also, the value representing efficiency showed the radial distance from the estimated production frontier to the decision-making unit (DMU) being under consideration.

\section{Specification of banks input and outputs}

In order to study productivity, data envelopment analysis (DEA) is employed in this study as a primary tool because it is widely used and still relevant for measuring the productivity given it has been proved to be sustained over time for 40 years with more than a thousand papers published in a year [22].
Accordingly, the intermediation approach was adopted in this study in classifying the input and output of banks, as supported in many studies [12]. This approach has been widely adopted as the initial stage of DEA, given the significant part that banks enact in providing financial intermediation.

In this study, the selection of inputs and outputs was steered by the process as depicted in several studies [3, $19,39,55]$. All variables employed in the nonparametric DEA were based on the MPI model as part of the initial stage of analysis, as depicted in Table 3.

According to Banker and Datar [10] and Cooper et al. [20], an approximation [assumption] is made in selecting the number of inputs and outputs in that the size of the sample needs to meet this assumption prior to progressing with the measurement of DEA as shown:

$$
n \geq \max \{m \times s, 3(m+s)\}
$$

where $n=$ number of decision-making unit (DMUs), $m=$ number of inputs, $s=$ number of outputs.

\section{Results}

The DEA-based MPI method is employed to examine the objective of this study, which is, to investigate the total factor productivity levels amid Islamic and conventional banking sector in South Asia, Southeast Asia and Middle East regions. The results are then tested using a parametric ( $t$ test) and nonparametric (Mann-Whitney [Wilcoxon] and Kruskal-Wallis) test in order to determine the variances in the productivity (y-axis) of Islamic and conventional banks. This test is widely used in prior banking productivity studies [14, 37]. Table 4 presents the summary statistics of data used to construct the productivity frontiers for Islamic and conventional banks. All the variables are measured in US\$m.

Furthermore, Table 5 shows the details results on productivity of Islamic and conventional banks and its decompositions. In addition, the results on Productivity of Islamic and conventional banks using the bank

Table 3 Variables of outputs and inputs. Source: Hassan et al. [30] and Johnes et al. [35]

\begin{tabular}{llll}
\hline Variable & Symbol & Variable Name & Definitions \\
\hline Outputs & $y 1$ & Loan & Net loans \\
& $y 2$ & Investment & Total securities \\
Inputs & $x 1$ & Deposits & $\begin{array}{l}\text { Total deposits, money } \\
\text { market and short-term } \\
\end{array}$ \\
& & & $\begin{array}{l}\text { funding } \\
\end{array}$ \\
& $x 2$ & Labour & Personnel expenses \\
& $x 3$ & Physical capital & Book value of fixed assets \\
\hline
\end{tabular}


Table 4 Summary statistics of outputs and input variables in the DEA model (US\$m)

\begin{tabular}{|c|c|c|c|c|c|}
\hline \multirow[t]{2}{*}{ Variables } & \multicolumn{2}{|l|}{ Output } & \multicolumn{3}{|l|}{ Input } \\
\hline & Total loans $(y 1)$ & Total Investment (y2) & Deposits $(x 1)$ & Labour (x2) & Capital (x3) \\
\hline \multicolumn{6}{|l|}{ Mean } \\
\hline Conventional banks & 7426.564 & 2787.981 & 10505.271 & 106.314 & 115.847 \\
\hline Islamic banks & 4019.186 & 938.938 & 5214.859 & 56.666 & 76.628 \\
\hline \multicolumn{6}{|l|}{ Minimum } \\
\hline Conventional banks & 0.500 & 0.019 & 0.800 & 0.008 & 0.008 \\
\hline Islamic banks & 0.344 & 0.054 & 0.979 & 0.067 & 0.029 \\
\hline \multicolumn{6}{|l|}{ Maximum } \\
\hline Conventional banks & $241,732.006$ & $86,833.757$ & $314,909.471$ & 2113.571 & 3834.810 \\
\hline Islamic banks & $62,276.160$ & $11,346.560$ & $74,287.733$ & 750.373 & 2095.493 \\
\hline \multicolumn{6}{|l|}{ SD } \\
\hline Conventional banks & $21,110.972$ & 7431.583 & $27,668.656$ & 229.472 & 274.103 \\
\hline Islamic banks & 7274.636 & 1626.269 & 8977.123 & 99.315 & 177.676 \\
\hline
\end{tabular}

number, specific years, specific regions and different income groups are illustrated in Tables 6 and 7 (see "Appendix"). All the graph levels of productivity in Middles East, Southeast Asia, South Asia and all regions by specific years, specific regions and different income groups are depicted in Figs. 2, 3, 4, 5, 6, 7, 8, 9, 10 and 11.

\section{Discussion}

\section{Productivity of Islamic and conventional banks and its decompositions}

Table 5 shows the geometric mean scores of the total factor productivity change (TFPCH) and its component, which is the Technical Change (TECHCH) and Efficiency Change (EFFCH) that can be decomposed into Pure Technical Efficiency Change (PTECH) and Scale Efficiency Change (SECH) for all banks (Panel A), conventional banks (Panel B) and IBs (Panel C). This analysis helps to understand the performance of the banks for each year.

Referencing Panel A in Table 5, it can be seen that all banks have, on average, exhibited a lower TFPCH regress of $-15.2 \%$ (0.848). The results show that all banks exhibited TFPCH regress of $-35.9 \%$ (0.641) in 2017. During the period of study, the $-15.2 \%$ (0.848) regress in TFPCH of all banks could be attributed mainly to the $-13.4 \%$ (0.866) decrease in TECHCH, as the EFFCH seems to have a decrease in the rate of $-2.1 \%(0.979)$. The decomposition of the EFFCH index consists of PTECH and SECH components indicating that the reason for the decrease in all banks EFFCH was mainly attributed to PTECH rather than SECH. Therefore, considering these findings, all banks are less efficient in the management of cost control, even though they have been operating at the optimal scale of operations.

Panel B of Table 5 depicts the results for conventional banks. As can be seen in the table, the conventional banks' average exhibited a TFPCH regress of $-14.7 \%$ (0.853). The results indicate 2017 represents a TFPCH regress of $-35.2 \%(0.648)$ for conventional banks. The decomposition of the TFPCH index into its TECHCH and EFFCH components reported that the regress in conventional banks' TFPCH was solely attributed to a $-12.1 \%(0.879)$ decrease in $\mathrm{TECHCH}$, as the EFFCH decreased at a rate of $-3.0 \%$ (0.970). The decomposition of the EFFCH index into its PTECH and SECH components indicates that the dominant sources that regress in conventional banks' EFFCH were mainly managerially rather than of an operational scale.

Similarly, Panel C of Table 5 shows the MPI average results of Islamic banks. The empirical findings seem to suggest that the Islamic banks' TFPCH decreased by $-11.2 \%(0.888)$ higher compared to their conventional banks' counterparts. The results show that for 2017 the TFPCH has a regress of $39.3 \%$ (0.607) and progress of $36.1 \%$ (1.361) in 2016 for Islamic banks. It can also be seen that within the period of study, the $-11.2 \%(0.888)$ regress in TFPCH of all banks could be attributed to the $-11.0 \%(0.890)$ decrease in $\mathrm{TECHCH}$, as the EFFCH seems to have a decline in the rate of $-0.2 \%(0.998)$. The decomposition of the EFFCH index into its PTECH and $\mathrm{SECH}$ components indicates that the decrease in EFFCH was mainly attributed to managerial factors rather than the scale.

Therefore, in summarising the findings, the TFPCH regress in conventional banks and Islamic banks mainly 
Table 5 Malmquist productivity index decompositions

\begin{tabular}{|c|c|c|c|c|c|}
\hline \multirow[t]{2}{*}{ Year } & \multicolumn{5}{|c|}{ INDICES } \\
\hline & TFPCH & TECHCH & EFFCH & PTECH & SECH \\
\hline \multicolumn{6}{|l|}{ Panel A: All banks } \\
\hline 2007 & 1.000 & 1.000 & 1.000 & 1.000 & 1.000 \\
\hline 2008 & 0.973 & 0.743 & 1.309 & 1.239 & 1.056 \\
\hline 2009 & 0.831 & 0.818 & 1.017 & 0.923 & 1.102 \\
\hline 2010 & 0.874 & 0.987 & 0.885 & 0.940 & 0.942 \\
\hline 2011 & 0.995 & 0.900 & 1.104 & 1.034 & 1.068 \\
\hline 2012 & 0.924 & 0.977 & 0.946 & 0.949 & 0.997 \\
\hline 2013 & 0.989 & 0.998 & 0.992 & 1.010 & 0.981 \\
\hline 2014 & 0.841 & 0.877 & 0.958 & 0.874 & 1.096 \\
\hline 2015 & 0.888 & 0.935 & 0.951 & 0.910 & 1.044 \\
\hline 2016 & 0.926 & 0.968 & 0.957 & 0.968 & 1.008 \\
\hline 2017 & 0.641 & 0.616 & 1.040 & 1.056 & 0.985 \\
\hline Geometric mean & 0.848 & 0.866 & 0.979 & 0.957 & 1.023 \\
\hline \multicolumn{6}{|c|}{$\begin{array}{l}\text { Panel B: Conventional } \\
\text { banks }\end{array}$} \\
\hline 2007 & 1.000 & 1.000 & 1.000 & 1.000 & 1.000 \\
\hline 2008 & 0.952 & 0.732 & 1.301 & 1.233 & 1.054 \\
\hline 2009 & 0.832 & 0.825 & 1.009 & 0.917 & 1.099 \\
\hline 2010 & 0.905 & 0.993 & 0.912 & 0.960 & 0.949 \\
\hline 2011 & 1.009 & 0.901 & 1.119 & 1.052 & 1.064 \\
\hline 2012 & 0.911 & 0.983 & 0.927 & 0.936 & 0.990 \\
\hline 2013 & 0.981 & 0.987 & 0.994 & 1.019 & 0.975 \\
\hline 2014 & 0.848 & 0.875 & 0.969 & 0.878 & 1.104 \\
\hline 2015 & 0.917 & 0.954 & 0.961 & 0.942 & 1.021 \\
\hline 2016 & 0.859 & 0.961 & 0.894 & 0.889 & 1.005 \\
\hline 2017 & 0.648 & 0.597 & 1.086 & 1.097 & 0.989 \\
\hline Geometric mean & 0.853 & 0.879 & 0.970 & 0.957 & 1.014 \\
\hline \multicolumn{6}{|c|}{ Panel C: Islamic banks } \\
\hline 2007 & 1.000 & 1.000 & 1.000 & 1.000 & 1.000 \\
\hline 2008 & 1.128 & 0.826 & 1.364 & 1.278 & 1.068 \\
\hline 2009 & 0.829 & 0.769 & 1.077 & 0.964 & 1.117 \\
\hline 2010 & 0.765 & 0.866 & 0.884 & 0.891 & 0.992 \\
\hline 2011 & 0.924 & 0.899 & 1.025 & 0.943 & 1.089 \\
\hline 2012 & 0.995 & 0.945 & 1.053 & 1.022 & 1.031 \\
\hline 2013 & 1.032 & 1.049 & 0.982 & 0.972 & 1.012 \\
\hline 2014 & 0.808 & 0.890 & 0.908 & 0.856 & 1.059 \\
\hline 2015 & 0.763 & 0.848 & 0.899 & 0.773 & 1.164 \\
\hline 2016 & 1.361 & 1.005 & 1.354 & 1.326 & 1.021 \\
\hline 2017 & 0.607 & 0.721 & 0.843 & 0.875 & 0.963 \\
\hline Geometric mean & 0.888 & 0.890 & 0.998 & 0.960 & 1.039 \\
\hline
\end{tabular}

The table presents the geometric mean of the bias-corrected bootstrap total factor productivity change (TFPCH) index and its mutually exhaustive components of technical change (TECHCH) and efficiency change (EFFCH) that is further decomposed into pure technical efficiency change (PTECH) and scale efficiency change (SECH)

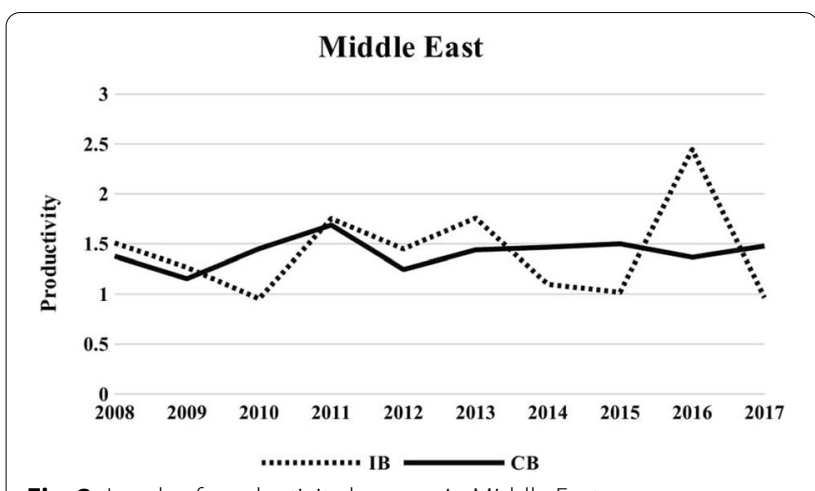

Fig. 2 Levels of productivity by years in Middle East

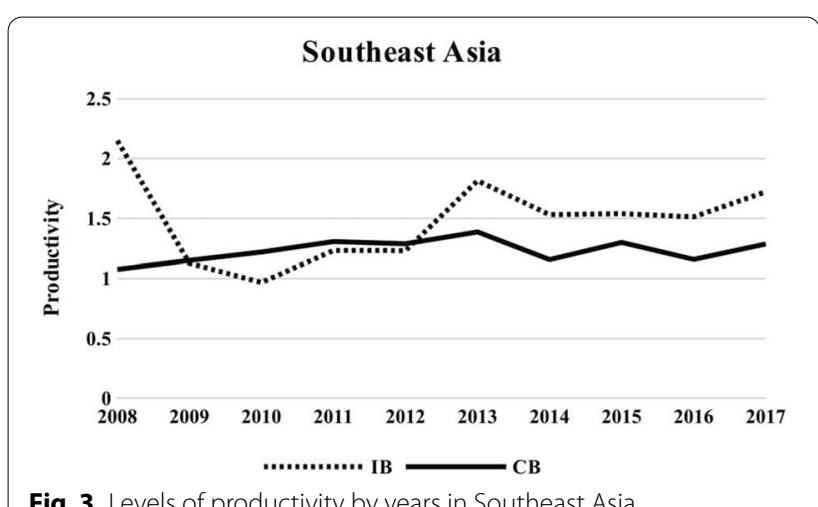

Fig. 3 Levels of productivity by years in Southeast Asia

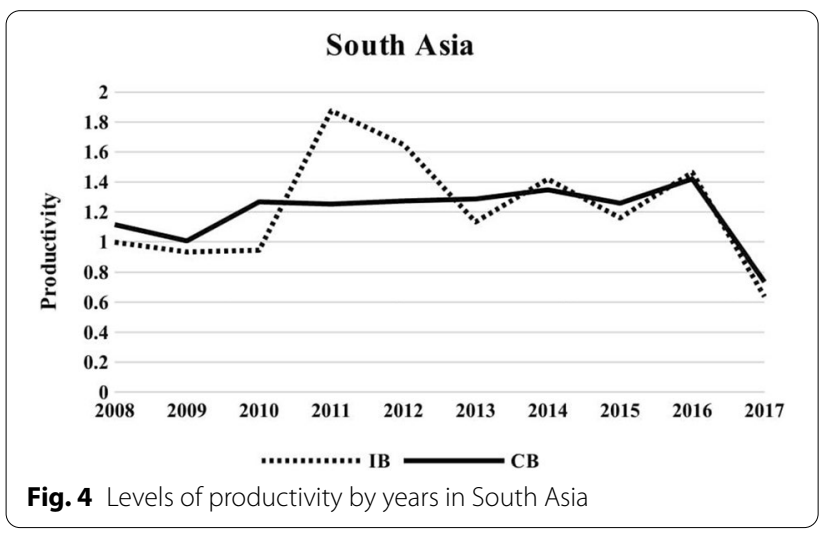

result from technological regression (TECHCH). Overall, the empirical findings indicate that the conventional banks and Islamic banks are operating at the optimal scale of operations but are less efficient in the management of cost control. 


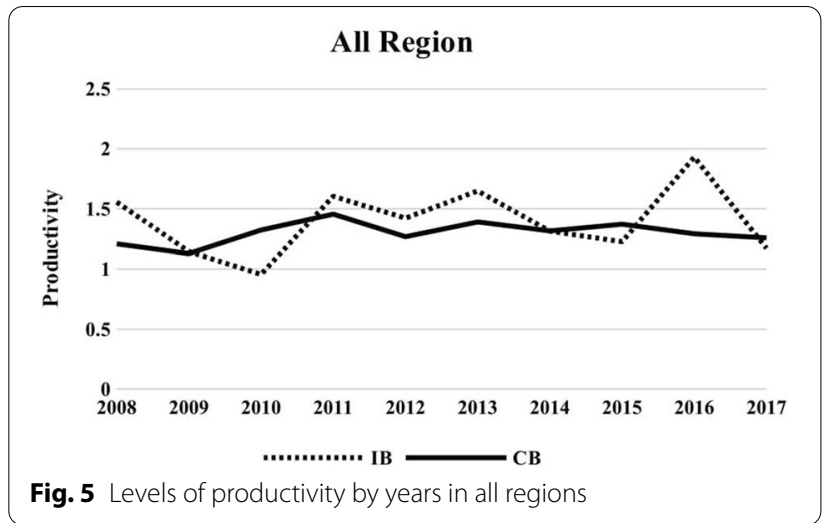

Fig. 5 Levels of productivity by years in all regions
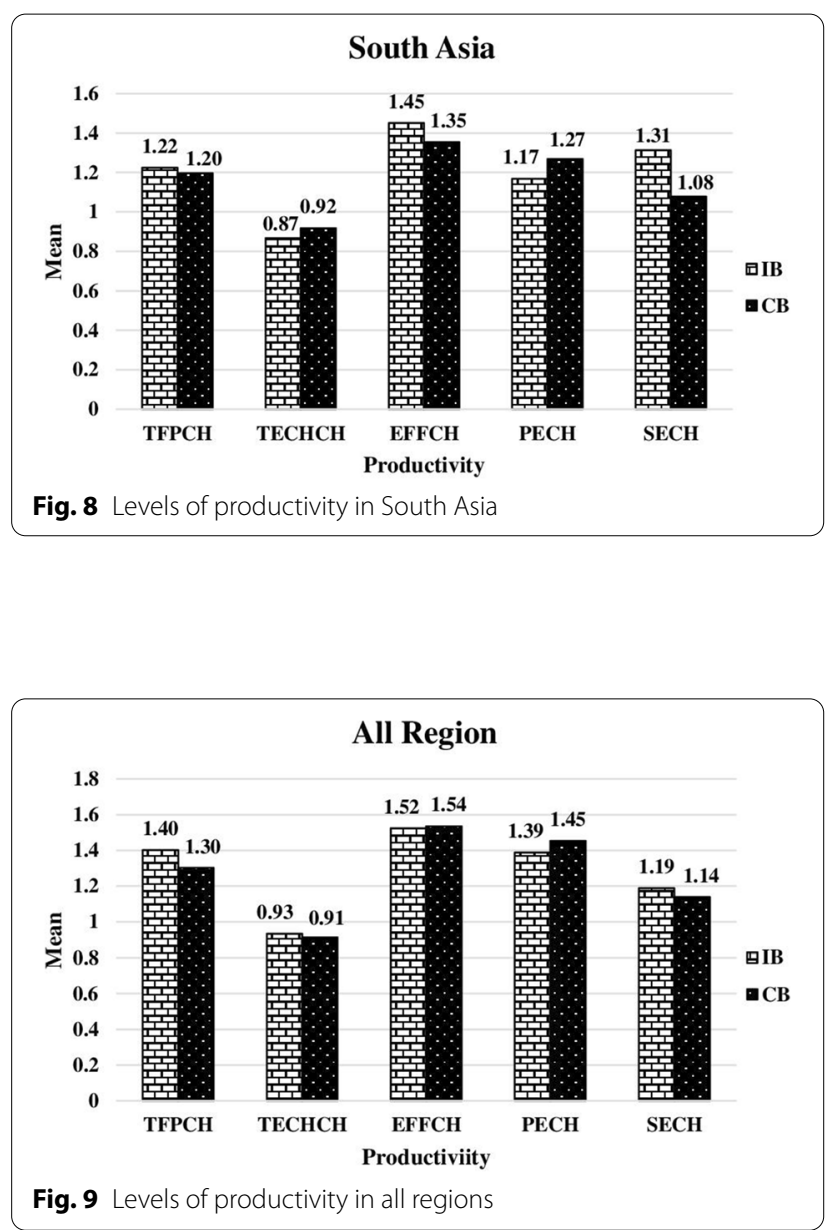

Fig. 6 Levels of productivity in Middle East

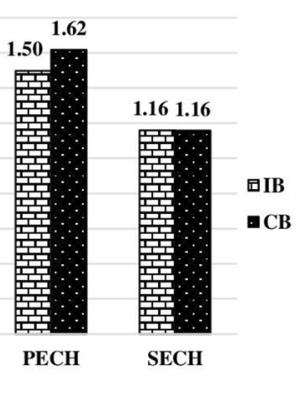

Fig. 9 Levels of productivity in all regions

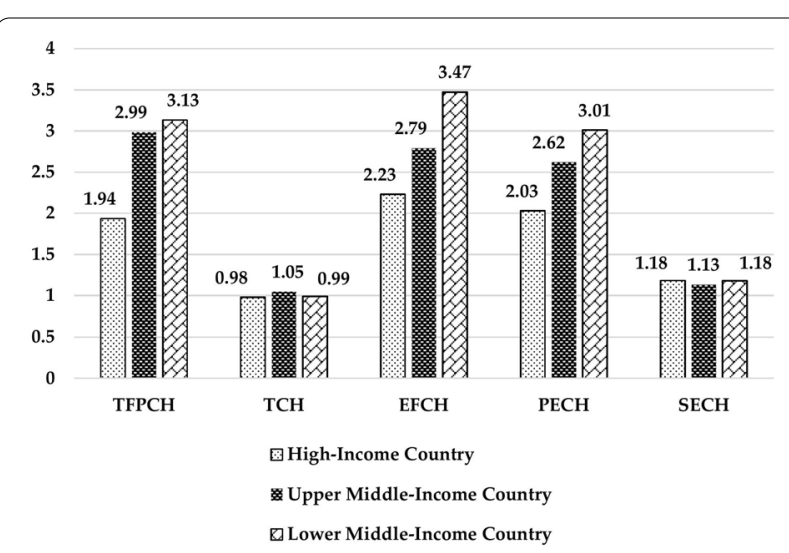

Fig. 10 TFPCH for Islamic Banks in Different Income Groups from Year 2008 to 2017 


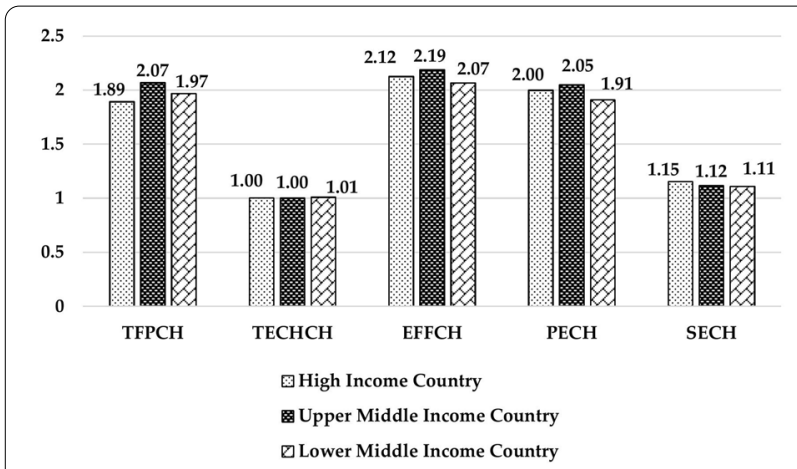

Fig. 11 TFPCH for Conventional Banks in Different Income Groups from Year 2008 to 2017

\section{Productivity of Islamic and conventional banks: an analysis} based on the number

In order to control for possible outliers or extreme observations, Table 6 (see "Appendix") reports the trend in the number and percentage of all banks that experienced productivity progress or regress during the period of study. Referencing Panel A in Table 6, in 2008, only 114 (34.44\%) of all banks experienced productivity growth and then increased substantially reaching 198 (55.62\%) banks in 2013. However, the number declined to 137 (37.64\%) banks in 2017. The result also shows that the number of banks that experienced technological progress increased from 77 (23.26\%) banks during 2008 to 196 $(55.06 \%)$ in 2013 but drastically declined to $81(22.25 \%)$ banks in 2017, Though the number of banks experienced technological regress declined from 228 (68.88\%) banks in 2008 to 159 (44.66\%) banks in 2013 but before radically increasing to $281(77.20 \%)$ in 2017.

Panel B of Table 6 presents the trend in the number and percentage of conventional banks that experienced productivity progress or regressed between 2008 and 2017. The results suggest that the number of conventional banks experienced productivity progress increased from 92 (31.83\%) banks in 2008 to 165 (53.92\%) in 2014. However, the number of conventional banks that experienced productivity progress decreased gradually to $114(37.75 \%)$ banks in 2017. Similarly, conventional banks exhibit technological regress decreasing from 200 (69.20\%) banks in 2008 to 132 (45.05\%) banks in 2013 and before rising to 237 (78.48\%) in 2017.

Furthermore, Panel C of Table 6 presents the trend in the number and percentage of Islamic banks that experienced productivity progress or regressed between 2008 and 2017. In 2008, only 22 (52.38\%) of Islamic banks experienced productivity growth, which increased substantially to $36(57.14 \%)$ banks in 2013. However, the number declined to 23 (37.10\%) banks in 2017. Likewise, Islamic banks which exhibited a technological progress rise from 10 (23.81\%) banks in 2008 to 36 (57.14\%) in 2013, reduced to $18(29.03 \%)$ banks in 2017. Further, Islamic banks that exhibited technological regress inclined from 28 (66.67\%) in 2008 to $50(78.13 \%)$ in 2014 with the number marginally declining to $44(70.97 \%)$ in 2017.

\section{Productivity of Islamic and conventional banks on specific years}

Observing in more detail in the ME region, as reflected in Fig. 2, the productivity indices of Islamic banks progressed in 2016 with 2.445 productivity indices and then regressed in 2010 (0.953). Furthermore, Fig. 3 reveals that productivity indices for both banks in the SEA region follow an inconsistent trend between 2008 and 2017, with productivity indices for Islamic banks peaking in 2008 (2.150) and in 2013 (1.815) staying relatively stable after that. While the Islamic banks reach their peak at 1.875 in 2011 in the SA region as reflected in Fig. 4, before slowly declining in the following year. Islamic banks and conventional banks in SA are rated as having the lowest productivity indices of 0.638 and 0.736 in 2017, whereas the productivity of Islamic banks in the ME and SEA was lower in 2010, at 0.953 and 0.967 productivity indices, respectively. On the other hand, ME conventional banks had the lowest productivity indices at 1.155 in 2009, while conventional banks in SEA had the lowest productivity indices of 1.075 in 2008.

Figure 5 shows the trend related to the productivity of Islamic and conventional banks in all regions between 2008 and 2017. As seen in Fig. 5, the productivity of Islamic banks outperforms conventional banks in most years following the GFC in 2008 and 2009. On average, both Islamic banks and conventional banks have productivity indices above 1.00, indicating that the banks' have experienced progress in their productivity compared to the prior year. We can also see productivity indices for both banks show the unevenness of the trend between 2008 and 2017, where productivity indices for Islamic banks peaked in 2008 (1.556) and 2011 (1.604), before gradually decreasing from 2013 (1.649) to 2015 (1.226) and reaching a peak in 2016 (1.931). However, the productivity of conventional banks from all regions remains relatively stable in the lowest level range of 1.129 in 2009 to the highest level of 1.455 in 2011.

The reason of this condition is Muslim population is increasing especially in Southeast Asian region which 
made substantial popularity in the ethical character and financial stability in Islamic finance product and services as an alternative to conventional financing mechanisms [41]. Moreover, the issuance of global Sukuk in 2012 has been growing in popularity and utilised by both corporate sector and sovereigns for raising fund in Southeast Asian country, in particular, Malaysia, followed by Indonesia to promote Shariah-based financial product that enabling these regions to dominate over 70 per cent of the world's Sukuk issuances [41]. Furthermore, South Asia has made investment for their infrastructure development which is one of the major obstacles to the economic growth in year 2016 [8]. Sukuk played an important role in financing the infrastructure projects in South Asia region [41].

To conclude, Fig. 5 shows the overall empirical mean productivity level in all regions indicating that Islamic banks have a higher overall productivity level compared to conventional banks [1.931 (2016) vs. 1.455 (2011)]. This suggests that the Islamic banks are more productive than conventional banks in managing their operations. The level of productivity in Islamic banks in all three regions (ME, SEA and SA) [2.445 (2016), 2.15 (2008), 1.875 (2011)], respectively, is higher than in conventional banks [1.689 (2011), 1.306 (2011), 1.348 (2014)].

\section{Productivity of Islamic and conventional banks in specific regions}

Figure 6 represents the productivity component of Islamic and conventional banks in $\mathrm{ME}$ countries between 2008 and 2017. The TFPCH are almost similar for both types of banks in the ME; Islamic banks (1.417) and conventional banks (1.418). The TFPCH progress in both banks results from higher $\mathrm{EFFCH}$, which means there is an improvement in the management of the banks. When looking at the decomposition of the EFFCH, both banks have progressed in $\mathrm{PECH}$. Figure 7 shows the productivity component of Islamic and conventional banks in SEA countries between 2008 and 2017. Here, overall, Islamic banks have higher TFPCH (1.488 vs. 1.233), TECHCH (0.977 vs. 0.918$), \mathrm{EFFCH}$ (1.513 vs. 1.469) and SECH (1.152 vs. 1.149 ), while conventional banks have slightly higher PECH (1.372 vs. 1.367) than Islamic banks. The TFPCH in both banks results from the EFFCH. When considering at the decomposition of EFFCH, both banks have progressed in $\mathrm{PECH}$.

Figure 8 confirms the productivity component of Islamic and conventional banks in SA countries between 2008 and 2017. Overall, Islamic banks have higher TFPCH (1.488 vs. 1233$)$, EFFCH (1.513 vs. 1.469$)$ and
SECH (1.152 vs. 1.149). While conventional banks are higher in TECHCH (0.977 vs. 0.918) and PECH (1.367 vs. 1.372) than Islamic banks. The TFPCH in both Islamic and conventional banks results from $\mathrm{EFFCH}$, same as for other regions. The decomposition of EFFCH shows that both banks have progressed in SECH.

To conclude, Fig. 9 reveals the overall empirical mean productivity level in all regions indicating that Islamic banks have a higher overall productivity level than conventional banks (1.402 vs. 1.302]. This suggests that Islamic banks are more productive than conventional banks in handling their respective operations. The level of productivity in Islamic banks in all three regions (ME, SEA and SA) $[1.417,1.488,1.224]$ is higher than in conventional banks $[1.418,1.233,1.196]$, respectively.

\section{Productivity of Islamic and conventional banks in different income groups}

Figure 10 represents TFPCH of Islamic banks in different income groups which are high-income, upper middleincome and lower middle-income countries from year 2008 to 2017. Overall, high-income countries have lowest TFPCH, TECHCH, EFFCH and PECH. While lower middle-income countries have higher TFPCH, EFFCH, $\mathrm{PECH}$ and SECH. The upper middle-income countries have slightly higher TECHCH than high-income countries and lower middle-income countries.

The reason of this condition can be related to the increasing number of Islamic banks in the upper middleincome countries and lower middle-income countries such as Malaysia, Indonesia, Pakistan and Bangladesh. High Muslim population with their income levels has a positive effect on the Islamic banking system development [16]. As the number of Islamic banks in these income groups is increasing especially in Malaysia and Indonesia, it creates a highly competitive market among them. According to Abedifar et al. [2], the coexistence of both banks in the market can motivate the banks to be more innovative and increase the efficiency of whole banking system by improving competition.

As we can see from Fig. 10, the TFPCH in all income group countries comes from the EFFCH and this means there is managerial change in the banks. According to Boukhatem and Moussa [16], countries that have adopted mixed legal system based on Common law and Islamic (Shariah) law enable them to be flexible in response to the shift in macroeconomic conditions has contributed to the Islamic banks development.

Figure 11 represents the TFPCH for conventional banks in different income groups from year 2008 to 2017. The upper middle-income countries have slightly higher TFPCH 
than high-income group countries and lower middleincome group countries. Most of the changes are come from the $\mathrm{EFFCH}$ due to managerial efficiency. This result is in line with the findings of Aluko and Ajayi [1]. They found that lower income countries tend to have more efficient banks than high-income countries. High-income countries have a larger size of banking industry and they face more competitive pressures that can lead to larger agency cost and higher overhead costs, subsequently leading to lower productivity in bank operation [25].

\section{Robustness tests}

Table 7 (see "Appendix") presents the significant difference between the productivity levels of Islamic and conventional banks in specific years and regions derived from the parametric ( $t$ test) and nonparametric (Mann-Whitney [Wilcoxon] and Kruskal-Wallis tests) tests. The empirical findings presented in Table 7 suggest that the Islamic banks are marginally more productive than conventional banks in all regions. However, the difference is only statistically significant during 2008 and 2016 (Panels A and I). On the other hand, Panels B, C, G, H and J in the $t$ test suggest that the conventional banks have been relatively more productive than Islamic banks. However, the results are only statistically significant in Panel C. The results from nonparametric tests further confirm the $t$ test results.

Whereas, for the ME region, the results imply that the TFPCH level for Islamic banks is more progressed than in conventional banks in six out of the 10 years under examination. The results are significant at a 5\% level in Panel I. However, it can also be observed that conventional banks have higher TFPCH than Islamic banks in the ME region and are statistically significant in Panels $\mathrm{C}$ and J. Notwithstanding, Islamic banks have been relatively more progressed in terms of productivity compared to conventional banks in Panels A, E, F, H, I and J in the SEA region. However, only Panels A and I are statistically significant at $10 \%$ and $5 \%$, respectively. Nevertheless, Panels D, E, G and I suggest that Islamic banks are more productive than conventional banks in the SA region but only statistically significant at $1 \%$ in Panel D. The results also suggest that conventional banks are more progressive than Islamic banks in SA the region in Panels A, B, C, F, H and J. However, the difference is insignificant.

When analysing the results further, the findings also show the component of the MPI, including the TECHCH, EFFCH and decomposition of EFFCH, namely PECH and $\mathrm{SECH}$. Here, the findings show that Islamic are relatively more productive, attributed to higher TECHCH and statistically significant in Panels E, F and J. On the other hand, conventional banks are present more $\mathrm{TECHCH}$ and are statistically significant at Panel H. Likewise, the EFFCH in
Islamic banks is higher in Panels D, E, $\mathrm{H}$ and I and lower in Panels A, B, C, F, G and J. When we look at the decomposition of EFFCH, Islamic banks are statistically significant to have been progressed in PECH, as reflected in Panels I and J. However, the Islamic banks only experienced SECH progress in Panel $\mathrm{H}$ and is statistically significant at the 5\% level.

Panel K of Table 7c presents the results based on all years and regions. Based on the results, Islamic banks are more productive than conventional banks with a mean difference of $(1.402>1.302=0.100)$. The results from the nonparametric tests further confirm the results from the $t$ test. These results are attributed to the progress in $\mathrm{TECHCH}$ with a mean difference of (0.019) and statistically significant at $10 \%$ levels. The mean difference between Islamic and conventional banks TFPCH is not statistically significant in all regions, though.

The ME, SEA and SA regions also show that Islamic banks are more productive than conventional banks in Panel K of Table 7c. In the ME region, the productivity levels are similar for both types of banks $(1.418=1.418)$; though, it is not significant at any level. The difference is only statistically significant in the SEA region with $5 \%$ levels. The productivity attributed to higher TECHCH is statistically significant at $1 \%$ levels. The results from the parametric $t$ test are further confirmed through the nonparametric Mann-Whitney (Wilcoxon) and Kruskal-Wallis tests.

The results on the means for TFPCH in the Islamic and conventional banks in SA revealed that the TFPCH in the Islamic banks has a higher mean compared to conventional banks $(1.224>1.196)$; however, it is not statistically significant. The progression in productivity for Islamic and conventional banks originates from the $\mathrm{TECHCH}$ and is significantly different at a $1 \%$ level (under the nonparametric test). Overall, the mean difference shows that Islamic banks are more productive than conventional banks in all regions, namely the ME, SEA and SA regions.

Therefore, in summary, it was revealed that Islamic banks tend to be more progressive compared to conventional banks but insignificantly different. This conclusion appears to be consistent with the results of earlier research that Islamic and conventional banks may not completely translate into visible distinctions. Given the benefit that conventional banks enjoy over the Islamic banks, where conventional banks have a very long history and expertise, their main income comes from interest, has very huge capital, spreads broadly and has much more advanced technology, the findings of this study are in favour of the later banking system. Beck et al. [11], for instance, point out that Islamic banks have produced products that emulate conventional banking products, replacing interest rate payments 
and discounting with fees and contingent payment arrangement. Likewise, Khan [40] concludes that there are considerable gaps between Islamic banking and finance principles and their real practice, but most of Islamic banking and finance remains technically indistinguishable from conventional banking. In addition, Bourkhis and Nabi [17] also point out that in Islamic bank, only $20 \%$ are committed to long-term and risk-sharing funding and argue that Islamic banks emulate conventional banks and diverge from their theoretical business model. The findings of Doumpos et al. [21], Hassan et al. [30], Bader et al. [9] and Mohamad et al. [47] are also in favour of this finding.

\section{Conclusions}

This study seeks to add to the literature on banks performance. As the Islamic banking growth is rapidly soaring, it is imperative to study their productivity. This paper aims to analyse total factor productivity change of Islamic and conventional banks covering 18 countries with dual-banking systems in the context of Middle East, Southeast Asia and South Asia regions. By using nonparametric DEA-based MPI method, the data are tested using parametric ( $t$ test) and nonparametric (Mann-Whitney and Kruskal-Wallis) tests. Although the theory suggests that there is distinctly difference between Islamic banks compared to conventional banks in the effect of various productivity determinants such the complexity, agency cost, level of maturity and development, empirical estimation suggests that there is no statistically significant difference between the total factor productivity (TFPCH) of the Islamic and conventional banks.

Further examination on the specific years for two banking types shows Islamic banks has exhibited a marginal productivity progress than conventional banks in nearly all the year. Moreover, this study also looked further into specific regions in the context of Middle East, Southeast Asia and South Asia regions. The findings suggest that Islamic banks are more productive than conventional banks in most of the years for all regions. Almost all the progression in productivity of Islamic and conventional banks are solely attributed to the increase in efficiency change (EFFCH). This signifies that both Islamic and conventional banks are efficient in their managerial.

Banks performance has attracted much concern in the banking and finance world. This study has provided important implication for policy makers and business practices. Therefore, determining the overall productivity level of Islamic banks can be a guidance to the policy makers to improve managerial performance, and investors and clients to make other decisions relating to investment and service quality. The progressive in productivity of the bank is expected to continuously improve the banks' profitability by providing a high-quality service at a minimum cost. One key enable for such commitment would require banking and finance sectors to find the mechanism such as policy matter, workforce trainings and supports to soar up the productivity levels on the institutions. The findings in this study are in line with the existing literature on finance and development.

Furthermore, several limitations are inherent in this study, in which future researchers could explore. First, as this study examined the TFPCH of banks between 2008 and 2017, to achieve a consistent and comparative analysis, relatively little information was collected. As such, there were various aspects of productivity patterns that could not be discussed. Therefore, further research is needed in the future, considering a longer period of time, in order to explore the key determinants of productivity progress in the banking industry.

Secondly, this analysis may be further improved if the ratings of the financial institution are used as one of the factors to assess if higher-rated banks are better than lower-rated banks or vice versa. In addition, the regulatory regime of the various countries may be another consideration. There are well-developed regulations for Islamic banks in some countries, while others do not. Some factors that may be taken into consideration are that Basel III was introduced during the 2007-08 financial crisis, which could have influenced the risk-taking conduct of financial institutions.

Due to its limitations, this study provides the avenue and incentives to seek greater insight for a more deepened understanding and investigation on the productivity levels of two banking types. Future research may consider investigating the different bank production measurements such as production approach and revenue approach as this study is using intermediation approach in determining the specifications of bank's input and output. Besides, the nonparametric frontier analysis can be combined with the parametric stochastic frontier analysis method to attain more robustness empirical evidence. This study, therefore, offers motivations for the institutions to formulate strategic choices to escalate the productivity level of the banks.

\section{Appendix}

See Tables 6 and 7. 


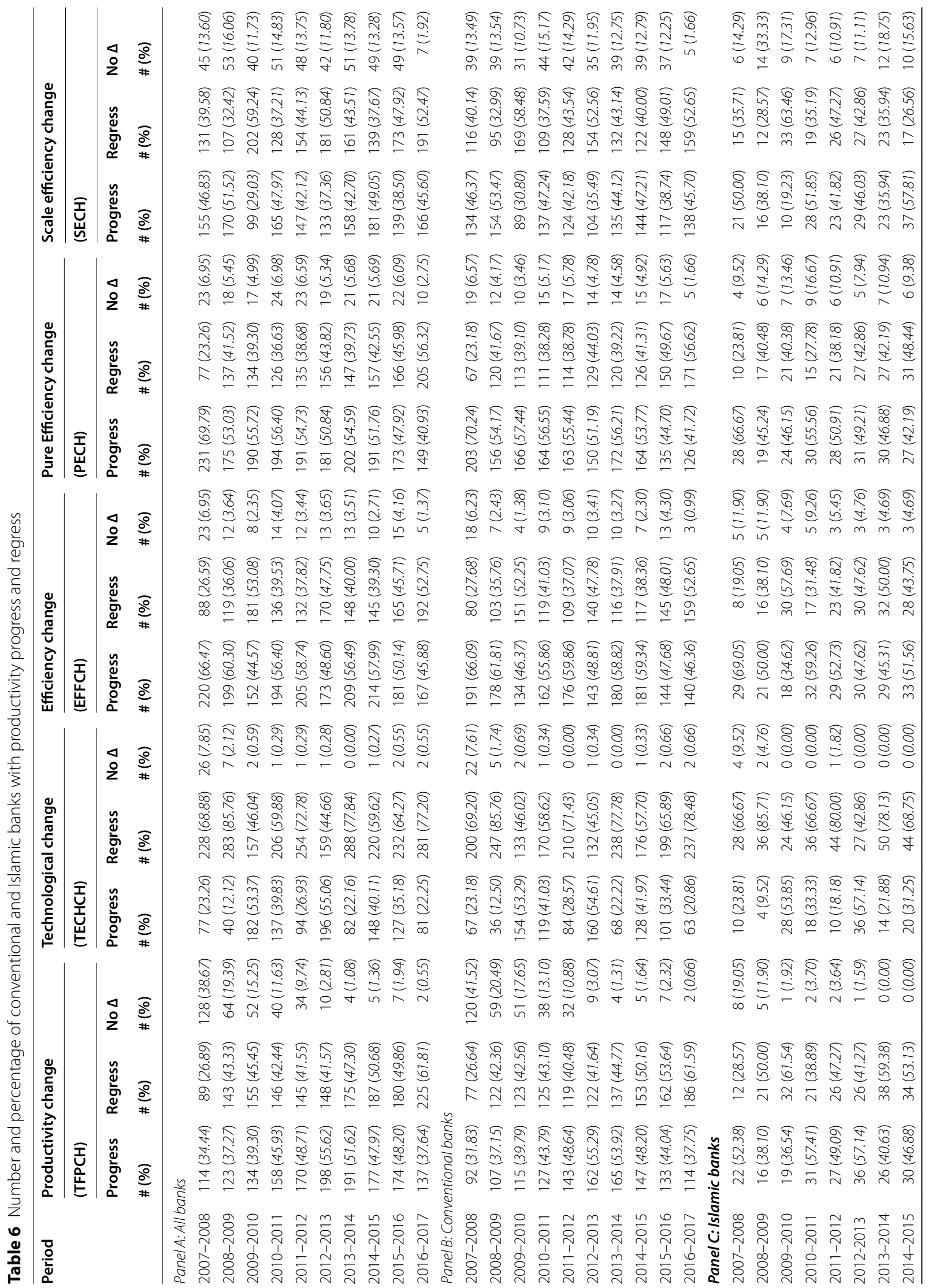




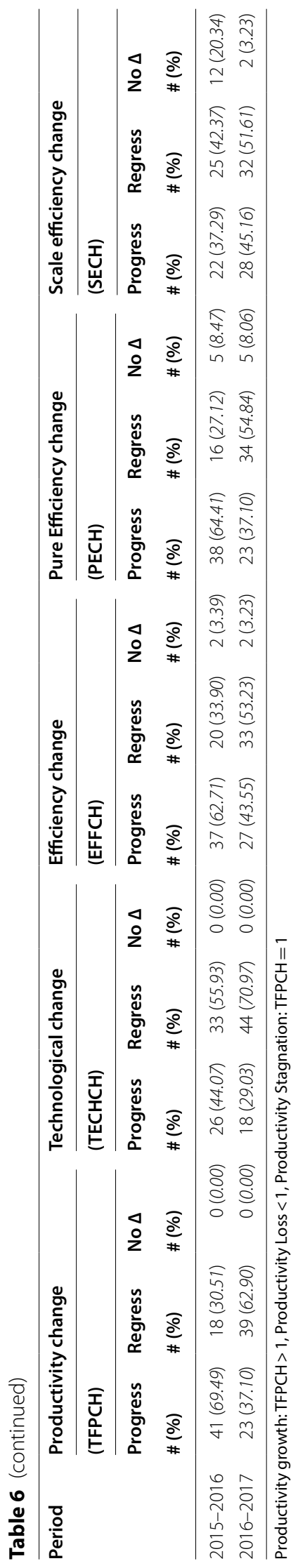









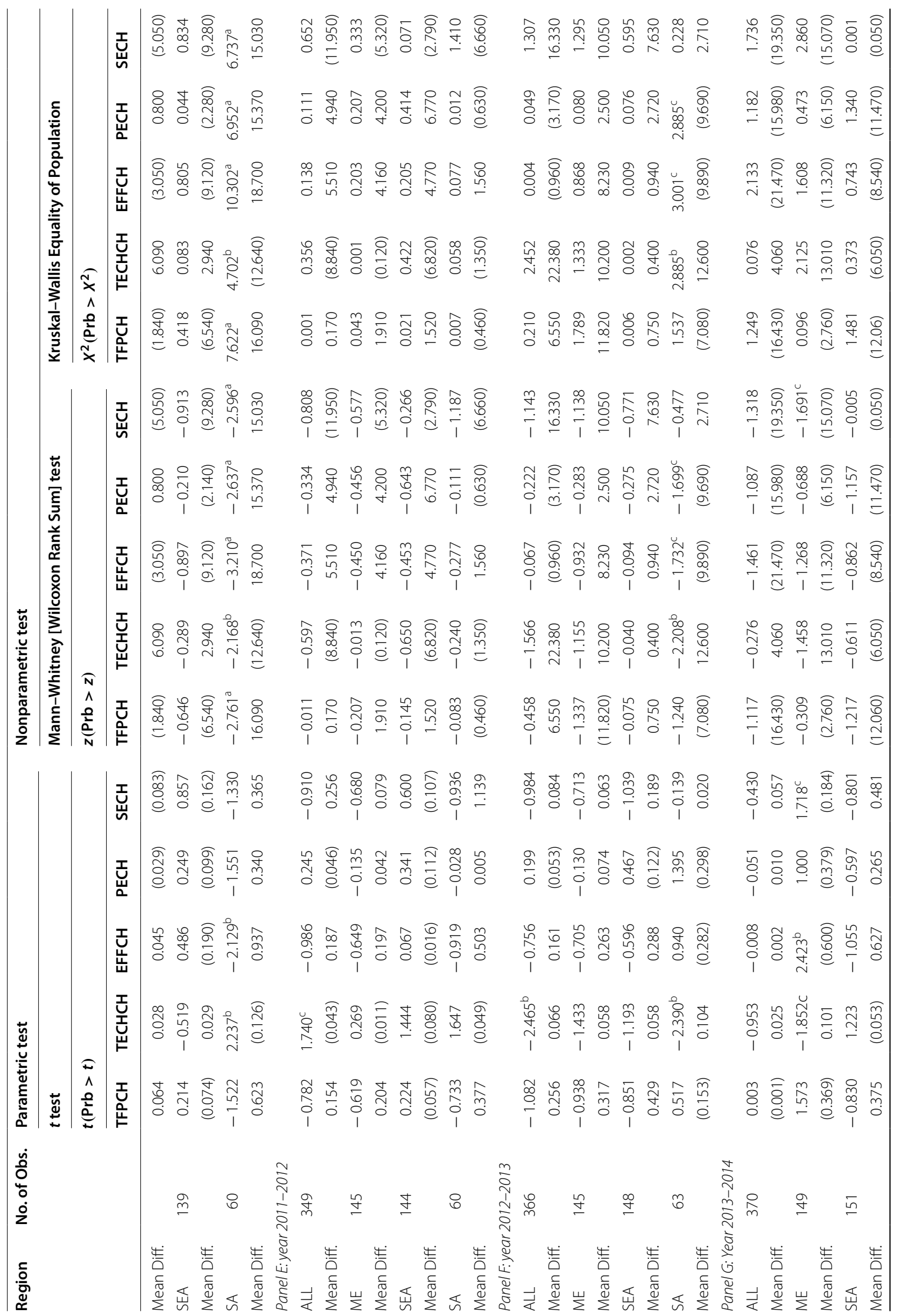




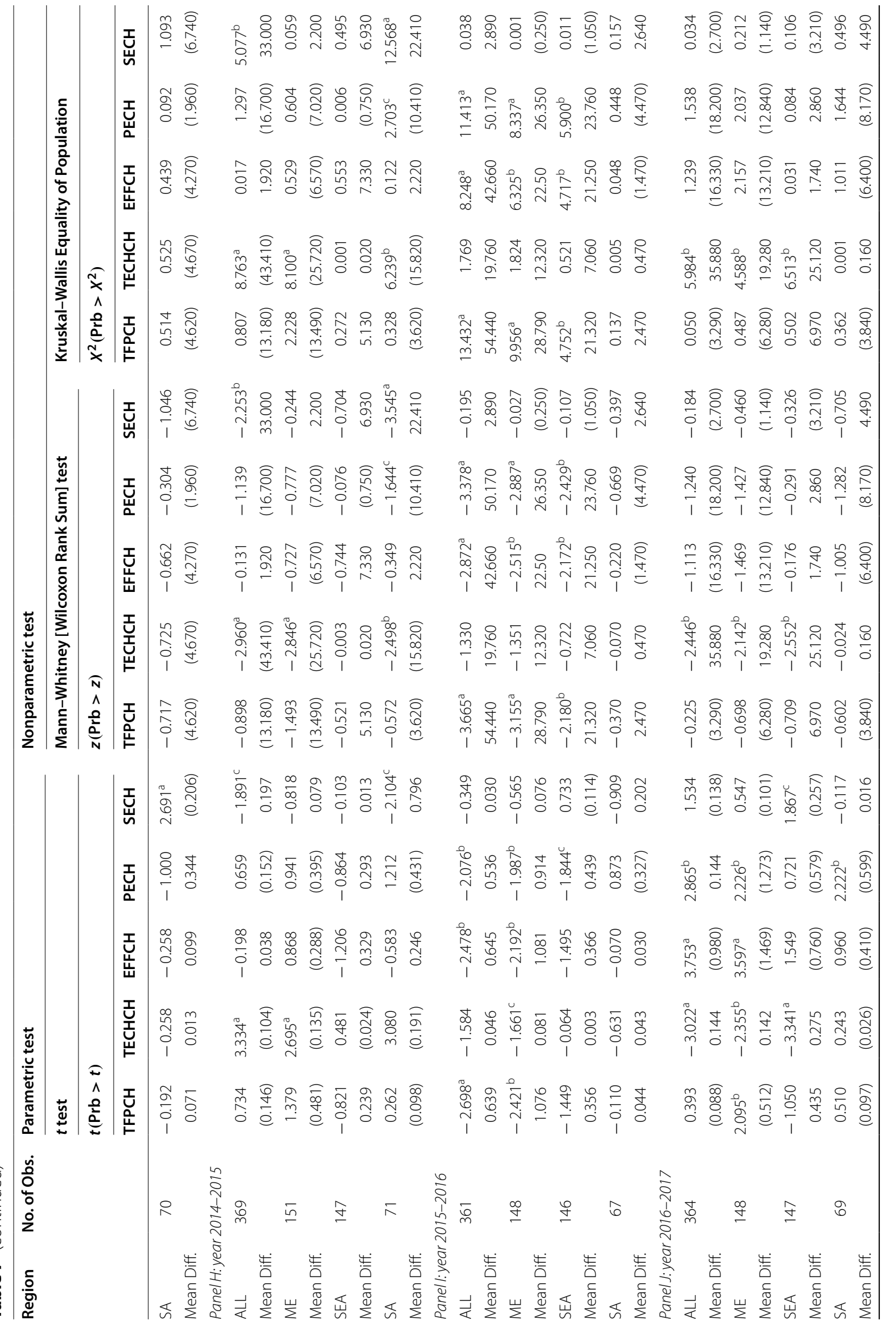




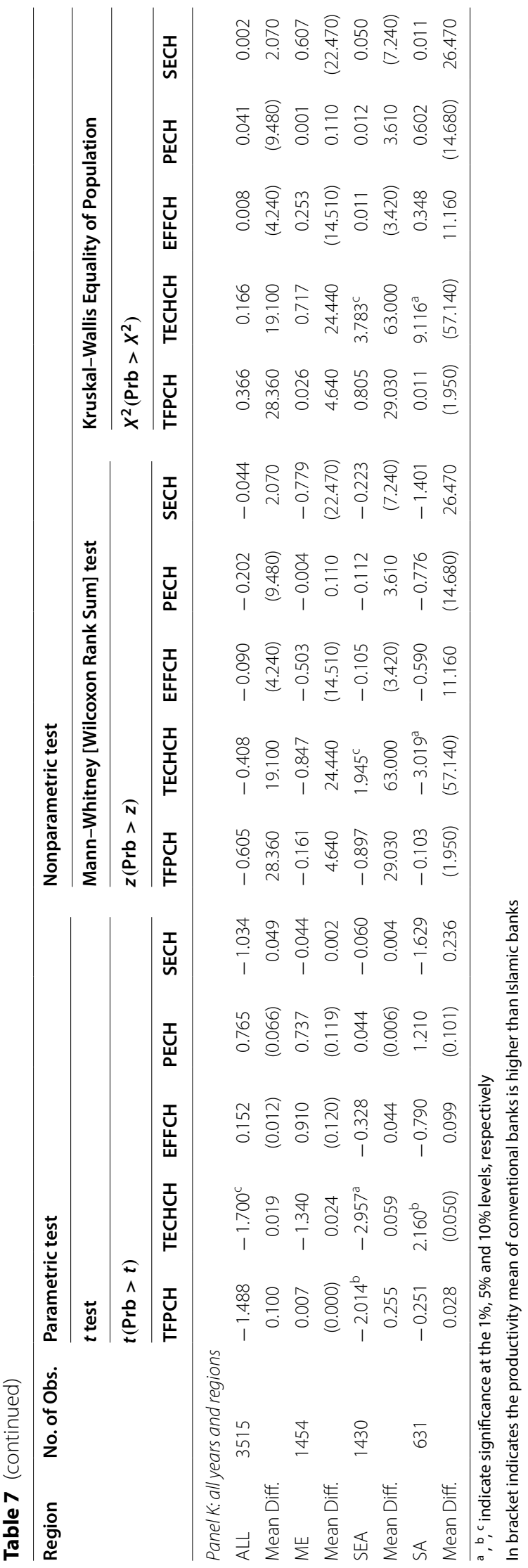

\section{Abbreviation}

DEA: Data envelopment analysis; TFP: Total factor productivity; TFPCH: TFP change; GFC: Global financial crisis; SA: South Asia; SEA: Southeast Asia; ME: Middle East; SAC: Shariah Advisory Committee; GCC: Gulf Cooperation Council; MPI: Malmquist productivity index; OIC: Organisation of Islamic Cooperation; SFA: Stochastic frontier analysis; TECHCH: Technical change; EFFCH: Efficiency change; SECH: Scale efficiency change; PTECH: Pure technical change; CRS: Constant returns to scale; VRS: Variable returns to scale; DMU: Decision-making unit.

\section{Acknowledgements}

Not applicable.

\section{Authors' contributions}

RVWJ structured the theoretical, research framework and analysed the data. FK conceived the idea and clarified the main issues in the research to ensure the novelty contribution and represent as the corresponding author. ARAL collects and provides data for this study. HIH performed the interpretation from the analysis results obtained. KMT ensures all the previous literature cited related to the issues discussed in the study and keeps research flow accordingly. All authors read and approved the final manuscript

\section{Funding}

This research is a result of a scholarship by (1) Universiti Putra Malaysia Grant Putra Vot No. 9632100 sponsored by Universiti Putra Malaysia that paid fees of data collection expenses from the research institution; (2) Fundamental Research Grant Scheme (FRGS) Vot No. FRGS/1/2015/SS01/UPM/02/1 5524716 sponsored by Malaysian Ministry of Higher Education that funded the travelling data collection expenses; (3) Universiti Putra Malaysia Grant IPM Vot No. 9473700 sponsored by Universiti Putra Malaysia that supported the nonparametric DEA software econometric; (4) Universiti Putra Malaysia Grant IPS Vot No. 9651500 sponsored by Universiti Putra Malaysia that paid the English professional service to polish and improvise the flow of the article and (5) Xiamen University Malaysia Research Fund Vote No. ISEM/0021 sponsored by Xiamen University Malaysia that funded the remunerators wages for the data collection.

\section{Availability of data and material}

The datasets used and/or analysed during the current study are available from the corresponding author on reasonable request.

\section{Declarations}

\section{Competing interests}

The authors declare that they have no competing interests.

\section{Author details}

${ }^{1}$ Putra Business School, Universiti Putra Malaysia, 43400 Serdang, Selangor, Malaysia. ${ }^{2}$ Labuan Faculty of International Finance, Universiti Malaysia Sabah, Jalan Sungai Pagar, 87000 Federal Territory of Labuan, Malaysia. ${ }^{3}$ School of Business and Economics, Universiti Putra Malaysia, 43400 Serdang, Selangor, Malaysia. ${ }^{4}$ Taylor's Business School, Faculty of Business and Law, Taylor's University, Taylor's Lakeside Campus, 1 Jalan Taylor's, 47500 Subang Jaya, Selangor Darul Ehsan, Malaysia. ${ }^{5}$ University of Economics and Human Science, Okopowa 59, 01-043 Warsaw, Poland. ${ }^{6}$ School of Economics and Management, Xiamen University Malaysia, 43900 Sepang, Selangor Darul Ehsan, Malaysia.

Received: 24 April 2020 Accepted: 13 April 2021

Published: 12 May 2021

\section{References}

1. Aluko O, Ajayi MA (2018) Determinants of banking sector development: evidence from Sub-Saharan African countries. Borsa Istanb Rev 18(2):122-139

2. Abedifar P, Hassan I, Tarazi A (2016) Finance-growth nexus and dualbanking systems: relative importance of Islamic banks. J Econ Behav Organ 132:198-215 
3. Alexakis C, Izzeldin M, Johnes J, Pappas V (2018) Performance and productivity in Islamic and conventional banks: evidence from the global financial crisis. Econ Model 1-14

4. Alqahtani F, Mayes D, Brown K (2017) Islamic bank efficiency compared to conventional banks during. J Int Financ 51:58-74

5. Alsharif M, Nassir A, Kamarudin F, Zariyawati M (2019) The productivity of GCC Islamic and conventional banks after Basel III announcement. J Islam Account Bus Res 10(5):770-792

6. Ang J, Cole R, Lin J (2000) Agency costs and ownership structure. J Finance 55(1):1-39

7. Ariff M (1988) Islamic banking. Asian-Pac Econ Literat 2(2):48-64

8. Asian Development Bank (2017) Meeting Asia's infrastructure needs. Asian Development Bank, Manila

9. Bader MK, Mohamad S, Ariff M, Hassan T (2008) Cost, revenue, and profit efficiency of Islamic versus conventional banks: international evidence using data envelopment analysis. Islam Econ Stud 15(2):23-76

10. Banker R, Datar S (1989) Sensitivity, precision, and linear aggregation of signals for performance evaluation. J Account Res 27(1):21-39

11. Beck T, Kunt AD, Merrouche $O$ (2013) Islamic vs. conventional banking: business model, efficiency and stability. J Bank Finance 37:433-447

12. Bhatia V, Basu S, Mitra SK, Dash P (2018) A review of bank efficiency and productivity. OPSEARCH 55:557-600

13. Bitar M, Madies P, Taramasco O (2017) What makes Islamic banks different? A multivariate approach. Econ Syst 41(2):215-235

14. Bitar M, Pukthuanthong K, Walker T (2020) Efficiency in Islamic vs. conventional banking: the role of capital and liquidity. Global Finance J $46(C): 1-40$

15. Bottazi G, Secchi A, Tamagni F (2008) Productivity, profitability and financial performance. Ind Corp Change 17(4):711-751

16. Boukhatem J, Moussa FB (2018) The effect of Islamic banks on GDP growth: Some evidence from selected MENA countries. Borsa Istanb Rev 18(3):231-247

17. Bourkhis K, Nabi MS (2013) Islamic and conventional banks'soundness during the 2007-2008 financial crisis. Rev Financ Econ 22(2):68-77

18. Charnes A, Cooper W, Rhodes E (1978) Measuring the efficiency of decision making units. Eur J Oper Res 2(6):429-444

19. Colwell R, Davis E (1992) Output and Productivity in Banking. Acand J Econ 94:S111-S129

20. Cooper W, Seiford L, Tone K (2002) Data envelopment analysis: a comprehensive text with models, applications, references and DEA-solver software. Kluwer Academic Publishers, Boston

21. Doumpos M, Hasan I, Pasiouras F (2017) Bank overall financial strength: Islamic versus conventional banks. Econ Model 64:513-523

22. Emrouznejad A, Yang G-L (2018) A survey and analysis of the first 40 years of scholarly literature in DEA: 1978-2016. Soc Econ Plan Sci 61:4-8

23. Fare R, Grosskopf S, Norris M, Zhang Z (1994) Productivity growth, technical progress, and efficiency change in industrialized countries. Am Econ Rev 84(1):66-83

24. Ganouati J, Essid H (2017) The sources of productivity change and efficiency in Islamic banking: application of Malmquist productivity index. Cent Eur Rev Econ Manag 1(4):35-67

25. Ghosh A (2016) Banking sector globalization and bank performance: a comparative analysis of low income countries with emerging markets and advanced economies. Rev Dev Finance 6(1):58-70

26. Habib SF (2018) Chapter 3: Islamic banking versus Conventional banking. In: Habib SF (ed) Fundamentals of Islamic finance and banking. Wiley, New York, pp 47-78

27. Hassan M, Aliyu S (2018) A contemporary survey of islamic banking literature. J Financ Stab 34:12-43

28. Hassan M, Aliyu S, Paltrinieri A, Khan A (2018) A review of Islamic investment literature. Econ Pap 38(4):345-380

29. Hassan M, Khan A, Paltrinieri A (2019) Liquidity risk, credit risk and stability in Islamic and conventional banks. Res Int Bus Finance 48:17-31

30. Hassan T, Mohamad S, Bader MK (2009) Efficiency of conventional versus Islamic banks: evidence from the Middle East. Int J Islam Middle Eastern Finance Manag 2(1):46-65

31. Houben V (2003) Southeast Asia and Islam. Ann Am Acad Polit Soc Sci 588:149-170

32. Imam P, Kpodar K (2016) Islamic banking: good for growth? Econ Model 59:387-401
33. International Monetary Fund (2015) IMF annual report 2015: tackling challenges together. IMF

34. Jensen M, Meckling W (1976) Theory of the firm: managerial behavior, agency costs and ownership structure. J Financ Econ 3(4):305-360

35. Johnes J, Izzeldin M, Pappas V (2014) A comparison of performance of Islamic and conventional banks 2004-2009. J Econ Behav Organ 103(Supplement):S93-S107

36. Kabir M, Worthington A, Gupta R (2015) Comparative credit risk in Islamic and conventional bank. Pacific Basin Finance J 34:327-353

37. Kamarudin F, Anwar NM, Nassir A, Sufian F, Tan KM, Hussain HI (2020) Does country governance and bank productivity Nexus matters? J Islam Market 1-52

38. Kamarudin F, Nordin BA, Muhammad J, Hamid MA (2014) Cost, revenue and profit efficiency of Islamic and conventional banking sector: empirical evidence from Gulf Cooperative Council countries. Glob Bus Rev 15(1):1-24

39. Kamarudin F, Sufian F, Loong FW, Anwar NM (2017) Assessing the domestic and foreign Islamic banks efficiency: insights from selected South east Asian countries. Future Bus J 3:33-46

40. Khan F (2010) How 'Islamic' is Islamic Banking? J Econ Behav Organ 76(3):805-820

41. Komijani A, Hesary FT (2018) An Overview of Islamic Banking and Finance in Asia. ADBI working paper series, 853, 1-14

42. Khan M, Bhatti M (2008) Islamic banking and finance: on its way to globalization. Manag Finance 34(10):708-725

43. Kopleman R (1986) Managing productivity in organizations: a practical, people-oriented perspective. McGraw Hill Book Company, New Delhi

44. Lassoued M (2018) Comparative study on credit risk in Islamic banking institutions: the case of Malaysia. Q Rev Econ Finance 70:267-278

45. Maredza A, Ikhide $P$ (2013) Measuring the impact of the global financial crisis on efficiency and productivity of the banking system in South Africa. Mediterr J Soc Sci 4(6):553-568

46. Mobarek A, Kalanov A (2014) Comparative performance analysis between conventional and Islamic banks: empirical evidence from OIC countries. Appl Econ 46(3):253-270

47. Mohamad S, Hassan T, Bader MK (2008) Efficiency of conventional versus Islamic banks: international evidence using the stochastic frontier approach (SFA). J Islam Econ 4(2):107-130

48. Paltrinieri A, Dreassi A, Rossi S, Khan A (2020) Risk-adjusted profitability and stability of Islamic and conventional banks: Does revenue diversification matter? Glob Finance J (In Press, Corrected Proof), 1-16

49. Rodoni A, Salim M, Amalia E, Rakhmadi R (2017) Comparing efficiency and productivity in Islamic banking: case study in Indonesia, Malaysia and Pakistan. J Islam Econ 9(2):227-242

50. Rosman R, Wahab NA, Zainol Z (2014) Efficiency of Islamic bank during the financial crisis: An analysis of Middle Eastern and Asian countries. Pac Basin Finance J 76-90

51. Said A (2013) Risks and efficiency in the Islamic banking systems: the case of selected Islamic banks in MENA region. Int J Econ Financ Issues 3(1):66-73

52. Saleh AS, Moradi-Motlagh A, Zeitun R (2020) What are the drivers of inefficiency in the Gulf Cooperation Council banking industry? A comparison between conventional and Islamic banks. Pacific Basin Finance J 60:

53. Siddiqi M (2006) Islamic banking and finance in theory and practice: a survey of state of the art. Islam Econ Stud 13:1-48. https://doi.org/10. 4197/islec.17-1.4

54. Sufian $F$ (2012) For which option is credit risk more representative on China banks' total factor productivity: efficiency change or technological progress? China Finance Rev Int 2(2):180-202

55. Sufian F, Habibullah MS (2014) Banks' total factor productivity growth in a developing economy: does globalisation matter? J Int Dev 26:821-852

56. Sufian F, Kamarudin F (2015) Determinants of revenue efficiency of Islamic banks. Int J Islam Middle Eastern Finance Manag 8(1):36-63

57. Sufian F, Kamarudin F (2017) Forced mergers on bank efficiency and productivity: evidence from semi-parametric Malmquist productivity index. Glob Bus Rev 18(1):19-44

58. Sufian F, Kamarudin F, Md. Nassir A (2017) Globalization and bank efficiency nexus: empirical evidence from the Malaysian Banking Sector. Benchmark Int J 24(5):1-8

59. The Asian Banker $(2009,2018) 100$ Largest Islamic Banks. Retrieved from The Asian Banker: http://www.theasianbanker.com/workspace.html? 
$\bmod =$ default\&method $=$ download $\& p=x g U g$ PkACJOGkKwBjdyYP7aK7F wG\%2BHsGOmfQtjrWZHFOW\%2FMpRqXgVFOsItEaCLOxoLFSkBhMoJvS\% 2Bd12z88Lv6w\%3D\%3D

60. Toumi K, Louhichi W, Vivian J-L (2012) Alternative financial decision principles: theoretical foundations of islamic banks' capital structure. In: Barnett W, Jawadi F (eds) Recent developments in alternative finance: empirical assessments and economic implications (international symposia in economic theory and econometrics. Emerald Group Publishing Limited, pp 157-172

61. Valderrama D (2003) Financial development, productivity, and economic growth. Retrieved from FRBSF Economic Letter: https://www.frbsf.org/ economic-research/publications/economic-letter/2003/june/financialdevelopment-productivity-and-economic-growth/

62. Wanke P, Azad M, Barros CP, Hassan M (2016) Predicting efficiency in Islamic banks: an integrated multicriteria decision making (MCDM) approach. J Int Financ Mark Inst Money 45:126-141

\section{Publisher's Note}

Springer Nature remains neutral with regard to jurisdictional claims in published maps and institutional affiliations.

\section{Submit your manuscript to a SpringerOpen ${ }^{\circ}$ journal and benefit from:}

- Convenient online submission

- Rigorous peer review

- Open access: articles freely available online

- High visibility within the field

- Retaining the copyright to your article

Submit your next manuscript at $\boldsymbol{\nabla}$ springeropen.com 